\title{
EVALUATION OF TOP-CROSS POPCORN HYBRIDS USING MIXED LINEAR MODEL METHODOLOGY
}

\author{
Emmanuel Arnhold ${ }^{1}$, Freddy Mora ${ }^{2 *}$, Ricardo G. Silva ${ }^{1}$, Pedro I.V. Good-God ${ }^{3}$, \\ and Marcos A. Rodovalho ${ }^{2}$
}

\begin{abstract}
The market for popcorn (Zea mays L.) has been continuously growing in Brazil fact has required the development of cultivars adapted to local environmental conditions. For this reason, the analytical objectives of this study were to evaluate top-cross popcorn hybrids in relation to popping expansion and grain yield in three different ecogeographic regions of Brazil, in order to estimate variance components using Restricted Maximum Likelihood (REML) and predict breeding values using Best Linear Unbiased Prediction (BLUP). Genetic evaluation considered a linear model with heterogeneous residual (environmental) variances. The Restricted Likelihood Ratio Test (RLRT) evidenced significant differences $(\mathrm{p}<0.01)$ for the genotypic effect. Grain yield showed a moderate heritable trait $\left(\mathrm{h}^{2}=0.26-0.39\right)$. A higher additive genetic control was evidenced for popping expansion $\left(\mathrm{h}^{2}=0.58-0.85\right)$. Genetic correlations and Spearman coefficient between both traits were negative, indicating that selection based on grain yield would have a negative effect on popping expansion. The top-cross hybrids showed an adequate grain yield, whereas the quality of the popcorn was lower than commercial standards.
\end{abstract}

Key words: popping expansion, REML, BLUP, improvement, Zea mays.

\section{INTRODUCTION}

The popcorn market in Brazil is continuously growing in terms of production and productivity (Mora and Scapim, 2007). Despite the important growth in the consumption of this product, diverse studies of the Ministry of Agriculture have determined that production is still limited with regards to the potential market. Close to 61000 tons are imported from Argentina and the United States each year (Scapim et al., 2006). It is estimated that Brazilian production is around $20000 \mathrm{t}$ (Carpentieri-Pípolo et al., 2002), but the national product shows inferior quality compared to the imported product, fact which interferes with the development of trade and productive interest. Nevertheless, this situation is being reverted by important advances achieved in the breeding programs.

\footnotetext{
${ }^{1}$ Universidade Federal de Maranhão, Centro de Ciências Agrárias e Ambientais (CCAA), BR 222, CEP 65550-000, Caixa Postal 9, Chapadinha, Maranhão, Brasil. (earnhold@pq.cnpq.br).

${ }^{2}$ Universidade Estadual de Maringá, Centro de Ciências Agrárias, Av. Colombo 5790, Bloco 05, CEP 87020-900, Maringá, Paraná, Brasil. *Corresponding author (morapoblete@gmail.com).

${ }^{3}$ Universidade Federal de Viçosa, Instituto de Biotecnologia Aplicada à Agropecuária - BIOAGRO, CEP 36570-000, Viçosa, Minas Gerais, Brasil.

Received: 31 October 2007.

Accepted: 25 March 2008.
}

Due to the extensive cultivated areas, the great diversity of eco-geographic regions, and the variations in management techniques, a high genotype-environment interaction is expected for the cultivation of the species. According to Gauch and Zobel (1988), environment diversity often makes it difficult to identify and recommend stable productive materials. Campbell and Jones (2005) defined genotype-environment interaction as the differential response of the genotypes for a particular trait in different environments. According to Lee et al. (2003), phenotypic stability has been recognized as an important objective of plant breeding, which is influenced by the genetic structure, the heterogenic and heterozygotic level of a cultivar.

Cruz et al. (2004) state that genotype-environment interaction studies, in spite of their great importance for breeding, do not provide detailed information about the behavior of each genotype in relation to environmental variations. According to these authors, adaptability and stability analyses are done with this objective in mind, thus making it possible to identify cultivars with a predictable behavior responding to environmental variations in specific or broad conditions. For this reason, adaptability and stability studies of popcorn cultivars have recently been carried out using different methodologies in Brazil (Nunes et al., 2002; Von Pinho et al., 2003). 
In the context of mixed linear models, interest in the classification (or ranking) of lineages and genotypes can be done through diverse techniques of which the following are the most common: Bayesian techniques (Mora and Perret, 2007; Gonçalves-Vidigal et al., 2008) and the BLUP procedure (Resende, 2002). The prediction of genetic values using BLUP depends on the estimates of the variance components associated with the random effects of the model. One of the preferred methodologies to estimate variance components is REML. This method was suggested by Thompson (1962) and later described by Patterson and Thompson (1971). The solution of the random effects in mixed models is obtained by means of the maximization of the joint density function which considers the fixed and random effects of the model. The equation system of mixed models also allows ascertaining Best Linear Unbiased Estimation (BLUE) for fixed effects. The variance components and the genetic values in these methods can be found through uni- and multivaried procedures.

The objectives of this study were: a) evaluate top-cross popcorn hybrids as a function of popping expansion and grain yield in different eco-geographic regions of Brazil; b) estimate variance components and predict genotypic values using the estimation/prediction procedure, based on Restricted Maximum Likelihood (REML) and Best Linear Unbiased Prediction (BLUP); c) apply the mixed linear model methodology to genetically evaluate topcross hybrids considering a mixed linear model with a heterogeneous residual (environmental) variance structure.

\section{MATERIALS AND METHODS}

The study took place during the agricultural season of 2000-2001 with three established assays of top-cross hybrids. The hybrids were obtained by crossing $\mathrm{S}_{3}$ families from the Beija-Flor and Viçosa populations (test cross). Both corresponded to selected popcorn populations due to their good combination capacity. The study originated in a dialelic crossing performed in the 1996-1997 agricultural season which included six populations belonging to the corn germplasm bank of the Universidad Federal de Viçosa in the Brazilian state of Minas Gerais. A popcorn breeding program was therefore initiated along with this study in order to obtain improved hybrids and populations.

The first top-cross assay with 60 hybrids (Site 1) took place in the experimental field of the Universidad Federal de Viçosa (20 ${ }^{\circ} 1^{\prime}$ 'S, 42 $47^{\circ}$ ' O, 720 m.a.s.l.) in the municipality of Coimbra, State of Minas Gerais, Brazil. The second assay with 77 hybrids (Site 2) was conducted in the Centro de Experimentación, Investigación $\mathrm{y}$ Extensión (CEPET/UFV) (18\%41' S, 49³4' O, 564 m.a.s.1.) in the municipality of Capinópolis, State of Minas Gerais. The third assay with 96 hybrids (Site 3) was performed in the Empresa de Investigación Agropecuaria del Estado de Río de Janeiro (PESAGRO-RJ) in Campos dos Goytacazes municipality, State of Rio de Janeiro. Forty-five hybrids, common to the three sites, were used in the joint analysis.

All the assays were set up in a random block design with three replications. The plots corresponded to $5 \mathrm{~m}$ rows spaced at $0.9 \mathrm{~m}$ with 30 plants per plot. All the experiments included cv. IAC 112 (simple hybrid) belonging to the Instituto Agronómico de Campinas (Campinas, Brazil), and cv. Zélia (triple hybrid) (Pioneer Hi-Bred, Johnston, Iowa, USA) as controls. Conventional sowing without supplementary irrigation was used. Sowing fertilization was carried out with $500 \mathrm{~kg} \mathrm{ha}^{-1}$ of 08:28:16 $\left(\mathrm{N}: \mathrm{P}_{2} \mathrm{O}_{5}\right.$ : $\mathrm{K}_{2} \mathrm{O}$ ) formula plus $120 \mathrm{~kg} \mathrm{ha}^{-1}$ urea cover, applied 30 days after the emergence of the plantlets. A preventive control of Spodoptera frugiperda was done weekly by applying insecticides.

Grain yield was evaluated in each plot (kg threshed grains plot $\left.{ }^{-1}\right)$ and popping expansion $\left(\mathrm{mL} \mathrm{g}^{-1}\right)$. Grain yield was corrected for a standard humidity of $14.5 \%$ and was transformed into $\mathrm{kg} \mathrm{ha}^{-1}$.

Popping expansion or expansion volume was obtained using the ratio between the volume of the popped kernel and the grain mass. A $30 \mathrm{~g}$ sample was collected in each plot coming from the central part of the ear of corn and prepared in a hot air popcorn pumper (Hot Air Popcorn Pumper H7340, Proctor Silex, Washington, North Carolina, USA), $1200 \mathrm{~W}$, y $280{ }^{\circ} \mathrm{C}$ during $2 \min 10 \mathrm{~s}$ (Arnhold et al., 2006; Mora and Scapim, 2007).

The following mixed linear model was used:

$$
y=X \beta+Z_{1} g+Z_{2} w+\varepsilon
$$

where $y$ is the vector of the phenotypic observations; $\beta$ is the vector of the fixed effects due to the block, site, and general mean; $g$ is the vector of the genotypic effects (assumed to be random); $w$ is the vector of the effects of the genotype-environment interaction (random); and $\varepsilon$ is the vector of residuals (random). Capital letters represent the incidence of the referred effects.

The observations and random effects were considered to comply with the following multivariate normal distribution (Mora and Arnhold, 2006):

$$
\left[\begin{array}{c}
y \\
g \\
w \\
e
\end{array}\right] \sim N M V\left(\left[\begin{array}{c}
X \beta \\
0 \\
0 \\
0
\end{array}\right],\left[\begin{array}{cccc}
V & Z_{1} G & Z_{2} W & R \\
G Z^{\prime} & G & \emptyset & \emptyset \\
W Z^{\prime} & \emptyset & W & \emptyset \\
R & \emptyset & \emptyset & R
\end{array}\right]\right)
$$

where 0 is the empty vector; $\emptyset$ is the empty matrix; $G$ is the inter-genotypic variance matrix; $\mathrm{W}$ is the interaction 
variance matrix; $\mathrm{R}$ is the residual variance matrix. Considering the previous model, BLUE for $\beta$, and BLUP for the random effects $g$ and $w$ are given for the following mixed model equation:

$$
\left[\begin{array}{ccc}
X^{\prime} R^{-1} X & X^{\prime} R^{-1} Z_{1} & X^{\prime} R^{-1} Z_{2} \\
Z_{1}^{\prime} R^{-1} X & Z_{1}^{\prime} R^{-1} Z_{1}+G^{-1} & Z_{1}^{\prime} R^{-1} Z_{2} \\
Z_{2}^{\prime} R^{-1} X & Z_{2}^{\prime} R^{-1} Z_{1} & Z_{2}^{\prime} R^{-1} Z_{2}+W^{-1}
\end{array}\right]\left[\begin{array}{c}
\beta \\
g \\
w
\end{array}\right]=\left[\begin{array}{c}
X^{\prime} R^{-1} y \\
Z_{1}^{\prime} R^{-1} y \\
Z_{2}^{\prime} R^{-1} y
\end{array}\right]
$$

The estimates of the variance components, necessary for obtaining genetic values, were determined using the REML method.

For the hybrid selection, considering the three sites as a whole (presence of interaction not significant) or within each site, the best 20 genotypes were selected considering productivity and popping extension. For this reason, topcross hybrids of the $\mathrm{S}_{3}$ families classified simultaneously in the 20 genotypes with greater genetic value for both traits.

The presuppositions of homoscedasticity were investigated with the MIXED procedure (SAS Institute, 1996). The Akaike Information Criterion (AIC) (Akaike, 1974) and Schwarz Bayesian Information Criterion (BIC) (Schwarz, 1978) as well as the Likelihood Ratio (LR) statistic were used jointly to confirm the homogeneousness hypothesis according to Mora and Scapim (2007).

The genetic prediction analyses were also done using the SAS MIXED procedure (SAS Institute, 1996). The statistical significance of the genotypic effects and the genotype-environment interaction were determined using the Restricted Likelihood Ratio Test (RLRT) (Mora and Scapim, 2007). In addition, the Spearman correlation coefficients were estimated (Newcom et al., 2005) for the rankings of both traits to determine the effects of indirect selection using the CORR (SAS Institute, 1996) procedure. The Bootstrap confidence intervals were computed as well (Mora and Arnhold, 2006).

\section{RESULTS AND DISCUSSION}

The mean grain yield values were $2285 \mathrm{~kg} \mathrm{ha}^{-1}$ in Coimbra (Site 1), $3091 \mathrm{~kg} \mathrm{ha}^{-1}$ in Capinópolis (Site 2), and $3524 \mathrm{~kg} \mathrm{ha}^{-1}$ in Campos dos Goytacazes (Site 3). The general productivity mean in the three assays was $2967 \mathrm{~kg} \mathrm{ha}^{-1}$. Therefore, the top-cross hybrids presented moderate productivity in general, considering that the mean productivity in the U.S.A. varies around $3500 \mathrm{~kg} \mathrm{ha}^{-1}$ (Pacheco et al., 1998). The mean productivity of the IAC 112 commercial hybrid was $3124 \mathrm{~kg} \mathrm{ha}^{-1}$ (mean of three sites).

The LR statistic as well as the AIC and BIC confirmed a significant heterogeneousness of the environmental variances $(\mathrm{p}<0.05)$ in both traits (Table 1). Silva et al. (2005) affirmed that the homogeneousness of residual variances, as well as the genetic type, is one of the most important incident statistics in genetic evaluation models

Table 1. Heteroscedastic and homoscedastic models (in relation to environmental variances) for yield (kg ha $\left.{ }^{-1}\right)$ and popping expansion ( $\left.\mathrm{mL} \mathrm{g}^{-1}\right)$ of popcorn genotypes evaluated in Brazil.

\begin{tabular}{|c|c|c|c|c|}
\hline \multirow[b]{2}{*}{ Parameters } & \multicolumn{2}{|c|}{ Yield } & \multicolumn{2}{|c|}{ Popping expansion } \\
\hline & $\begin{array}{l}\text { Common } \\
\text { variance }\end{array}$ & Heterogeneity & $\begin{array}{l}\text { Common } \\
\text { variance }\end{array}$ & Heterogeneity \\
\hline Genotypic variance $\left(\sigma_{g}^{2}\right)$ & 51332 & 57366 & 7.7316 & 7.9388 \\
\hline Interaction variance $\left(\sigma_{w}^{2}\right)$ & 13796 & 15993 & 0.7882 & 0.3747 \\
\hline Residual variance $\left(\sigma_{e}^{2}\right)$ & 394538 & - & 10.5071 & - \\
\hline Residual variance Site $1\left(\sigma_{e 1}^{2}\right)$ & - & 523964 & - & 17.0492 \\
\hline Residual variance Site $2\left(\sigma_{e 2}^{2}\right)$ & - & 285910 & - & 4.1058 \\
\hline Residual variance Site $3\left(\sigma_{e 3}^{2}\right)$ & - & 360875 & - & 11.3752 \\
\hline-2 RLL & 6876.6 & 6865.4 & 2395.5 & 2346.3 \\
\hline AIC & 6882.6 & 6875.4 & 2401.5 & 2356.3 \\
\hline BIC & 6888.2 & 6884.9 & 2407.1 & 2365.8 \\
\hline LR & - & 11.2 & - & 49.2 \\
\hline P-value for LR & - & 0.0107 & - & $<0.0001$ \\
\hline
\end{tabular}

RLL: restricted likelihood logarithm; AIC: Akaike information criterion (1974); BIC: Bayesian information criterion (Schwarz, 1978); LR: likelihood ratio. 
using BLUP. A model of heterogeneous variances in a mixed linear model of genetic evaluation of top-cross popcorn families was used with this result.

With the adjustment for heterogeneousness of the residual variances, the results of the Likelihood Ratio Test (LRT) indicated that the family effect was statistically significant $(\mathrm{p}<0.01)$, contrary to family-site interaction $(p>0.05)$. Grain production in this experiment showed a moderate heritability trait $\left(\mathrm{h}^{2}=0.26\right.$ to 0.39 ; Table 2$)$. For popping extension, the heritability value varied from 0.58 to 0.85 exhibiting a greater additive genetic control (Table 2 ). This genetic variation indicates a providential situation for the inter-genotypic selection (Mora and Scapim, 2007). The heritability of popping expansion is indicated in the literature (Arnhold et al., 2006). In a genetic assay with $\mathrm{S}_{2}$ families of the Beija-Flor corn population, Santos et al. (2004) estimated heritability in broad terms of 0.72 for popping expansion. Vilarinho et al. (2003) found lower heritabilities with the same population, varying from 0.60 to 0.32 in $S_{1}$ and $S_{2}$ families, respectively.

Genetic prediction for corn grain yield based on the family effect (via BLUP) of the best 20 genotypes is shown in Table 3. Considering this genetic prediction, it is observed that $(\mathrm{u}+\mathrm{g})$ nine top-cross hybrids exceeded their mean value at IAC 112, emphasizing the HT 26 hybrid. The mean value of HT 26 was $3398 \mathrm{~kg} \mathrm{ha}^{-1}$ considering the joint genotypic values predicted in the three sites. Rivas and Barriga (2002) mentioned the importance of the choice of parents that result in superior hybrid combinations for a breeding program that obtains new varieties through hybridizations. This selection can also be done by evaluating the combining capacities of the genotypes to be used which will give information on which ones will be the most favorable to improve the traits of interest.

In the context of mixed linear models, Piepho and Möhring (2006) reported the usefulness of this procedure in the selection of agronomical turnip (Brassica napus L.) cultivars in advanced stages of a breeding program, demonstrating that the REML method is preferable to Maximum Likelihood (ML) to estimate variance components, and BLUP is preferable to BLUE. In mixed linear models, the standard procedure preferred to estimate variance components is REML (Mora and Scapim, 2007). Just like the ML method, the REML procedure is iterative and demands residual normality since it is based on the density function of the normal distribution. However, the advantage of REML is that is considers the loss of the degrees of freedom due to the fixed effects of the model, providing unbiased estimates, and minimum variance for balanced data (Marcelino and Iemma, 2000).

Table 4 shows the ranking of the best 20 genotypes for popping expansion based on the prediction of genetic values via BLUP. The superiority of the IAC 112 and Zelia commercial hybrids was clearly verified in this table. The best-quality top-cross hybrid (HT 23) showed a predicted genotypic value of $27.11 \mathrm{~mL} \mathrm{~g}^{-1}$ and was superior to the other top-cross hybrids in the three sites. The mean value of popping expansion in the three assays was $22.68 \mathrm{~mL} \mathrm{~g}^{-1}$. There was also a great variation between environments for popping expansion, Campos dos Goytacazes (Site 3) was again the most favorable with a mean of $28.71 \mathrm{~mL} \mathrm{~g}^{-1}$, followed by Coimbra $\left(23.03 \mathrm{~mL} \mathrm{~g}^{-1}\right)$ and Capinópolis $\left(16.31 \mathrm{~mL} \mathrm{~g}^{-1}\right)$.

In order to commercialize a popcorn population, it must have a minimum popping expansion of $20 \mathrm{~mL} \mathrm{~g}^{-1}$, and lower values produce popcorn that appears very rigid with many kernels not popping, a trait of unimproved populations or varieties (Mora and Scapim, 2007). According to Matta and Vianna (2001), popping expansion of good-quality popcorn, imported and commercialized in Brazil, varies between 33 and $38 \mathrm{~mL} \mathrm{~g}^{-1}$ depending on the commercial brand. Therefore, despite adequate productivity in this study, the top-cross hybrids showed limited popping expansion.

Table 2. Estimates of variance components using the Restricted Maximum Likelihood (REML) method and heritability for yield and popping expansion of popcorn, considering a mixed linear model with heterogeneous residual variances.

\begin{tabular}{lcc}
\hline Parameters & Yield & Popping expansion \\
\hline Family variance $\left(\sigma_{f}^{2}\right)$ & kg ha $^{-\mathbf{1}}$ & $\mathbf{~ m L ~} \mathbf{~ g}^{-1}$ \\
Residual variance site $1\left(\sigma_{e 1}^{2}\right)$ & 62226 & 8.091 \\
Residual variance site 2 $\left(\sigma_{e 2}^{2}\right)$ & 538088 & 17.792 \\
Residual variance site $3\left(\sigma_{e 3}^{2}\right)$ & 297978 & 4.205 \\
Heritability site $1\left(\sigma_{s 1}^{2}\right)$ & 369553 & 11.590 \\
Heritability site $2\left(\sigma_{s 2}^{2}\right)$ & 0.258 & 0.577 \\
Heritability site $3\left(\sigma_{s 3}^{2}\right)$ & 0.385 & 0.852 \\
\end{tabular}


Table 3. The twenty best genotypes in relation to predicted breeding values using Best Linear Unbiased Prediction (BLUP) for grain yield of popcorn families evaluated in Coimbra and Capinópolis (Minas Gerais), and Campos dos Goytacazes (Rio de Janeiro), Brazil.

\begin{tabular}{lcccc}
\hline & \multicolumn{3}{c}{ Grain production $\left(\mathbf{k g ~ h a} \mathbf{~}^{-1}\right)$} \\
\cline { 2 - 5 } Genotype & $\boldsymbol{g}$ & $\boldsymbol{u}+\boldsymbol{g}$ & $\mathbf{G a i n}$ & New mean \\
\hline HT 26 & 431.0 & 3398.0 & 431.0 & 3398.0 \\
HT 42 & 366.9 & 3333.9 & 399.0 & 3365.9 \\
HT 17 & 360.8 & 3327.8 & 386.3 & 3353.2 \\
HT 10 & 357.8 & 3324.8 & 379.2 & 3346.1 \\
HT 25 & 291.6 & 3258.5 & 361.6 & 3328.6 \\
HT 24 & 3249.2 & 348.4 & 3315.4 \\
HT 9 & 282.3 & 3232.4 & 336.6 & 3303.5 \\
HT 41 & 265.5 & 3200.8 & 323.7 & 3290.7 \\
HT 8 & 233.9 & 3167.4 & 310.0 & 3277.0 \\
IAC 112 & 3130.8 & 295.4 & 3262.4 \\
HT 33 & 200.4 & 3083.5 & 279.1 & 3246.1 \\
HT 7 & 163.9 & 3071.9 & 264.6 & 3231.6 \\
HT 44 & 116.6 & 3065.6 & 251.9 & 3218.8 \\
HT 13 & 104.9 & 3059.0 & 240.5 & 3207.4 \\
HT 39 & 98.7 & 3057.5 & 230.5 & 3197.4 \\
HT 6 & 92.1 & 3057.5 & 221.7 & 3188.7 \\
HT 37 & 90.6 & 3054.2 & 213.8 & 3180.8 \\
HT 4 & 3044.2 & 206.2 & 3173.2 \\
HT 16 & 30.5 & 199.1 & 3166.0 \\
HT 38 & 87.3 & 2987.5 & 3157.1 \\
\hline
\end{tabular}

$g:$ is the value of the predicted genotypic effect; $u+g$ : is the mean value plus the genotypic effect.

It can be verified, by analyzing Tables 3 and 4 , that only some top-cross hybrids (30\%) were classified among the best 20 genotypes for both the predicted genotypic values of grain yield and popping expansion. The exception occurred for the HT 4, 6, 7, 16, 38, 39, and IAC 112 hybrids. This was expected and occurred due to the existence of a general negative genetic correlation estimated between grains and popping expansion (Arnhold et al., 2006). Indeed, the genetic correlation calculated between the predicted genotypic values of both traits (considering the whole ranking) was -0.37 (Site 1), -0.36 (Site 2), and -0.34 (Site 3). These results coincided with the Spearman correlation estimates (Table 5).

The confidence intervals in Sites 2 and 3 did not include the zero value for the Spearman coefficient estimate calculated between the rankings of both traits, indicating that the selection based on corn grain yield would have a negative effect on popping expansion, and vice versa. This result is extensively reported in the literature, for example, Sawazaki (1995) and Coimbra et al. (2001) confirmed that popcorn grain production is inversely correlated (negative association) with popping expansion. Mora and Arnhold(2006) estimated a Spearman correlation coefficient which was not significant. It was based on the calculations of BLUP rankings of both traits in $\mathrm{S}_{3}$ corn families and indicated that selection for popping expansion will not have a significant effect on production. However, obtaining positively correlated responses between grain production and popping expansion can be attained through determined simultaneous selection processes between both traits (Arnhold et al., 2006; Mora and Scapim, 2007). Arnhold et al. (2006) mentioned that the negative association between popping expansion and yield interfered with obtaining gains for simultaneous selection when referring to the two traits in population improvement. From the genetic point of view, this phenomenon indicates that both traits could be controlled by distinct genes.

In this study, it was possible to investigate and select more productive genotypes with greater popping expansion that were more adapted and stable in relation to these traits (in the absence of genotype-environment interaction). From the breeding point of view, in accordance with Soto et al. (2004), commercial corn hybrids are assigned to 
Table 4. Twenty best genotypes in relation to predicted breeding values using Best Linear Unbiased Prediction (BLUP) for popping expansion of popcorn families evaluated in Coimbra and Capinópolis (Minas Gerais), and Campos dos Goytacazes (Rio de Janeiro), Brazil.

\begin{tabular}{|c|c|c|c|c|}
\hline \multirow[b]{2}{*}{ Genotype } & \multicolumn{4}{|c|}{ Popping expansion $\left(\mathrm{mL} \mathrm{g}^{-1}\right)$} \\
\hline & $g$ & $u+g$ & Gain & New mean \\
\hline IAC 112 & 7.48 & 30.16 & 7.48 & 30.16 \\
\hline ZELIA & 7.37 & 30.05 & 7.42 & 30.10 \\
\hline HT 23 & 4.43 & 27.11 & 6.42 & 29.10 \\
\hline HT 14 & 2.68 & 25.36 & 5.49 & 28.17 \\
\hline HT 46 & 2.26 & 24.94 & 4.84 & 27.52 \\
\hline HT 4 & 2.12 & 24.80 & 4.39 & 27.07 \\
\hline HT 6 & 2.10 & 24.78 & 4.06 & 26.74 \\
\hline HT 30 & 2.06 & 24.75 & 3.81 & 26.49 \\
\hline HT 20 & 2.02 & 24.70 & 3.61 & 26.29 \\
\hline HT 18 & 1.67 & 24.35 & 3.42 & 26.10 \\
\hline HT 43 & 1.55 & 24.24 & 3.25 & 25.93 \\
\hline HT 11 & 1.42 & 24.10 & 3.10 & 25.78 \\
\hline HT 16 & 1.41 & 24.09 & 2.97 & 25.65 \\
\hline HT 22 & 1.38 & 24.06 & 2.85 & 25.53 \\
\hline HT 7 & 1.28 & 23.97 & 2.75 & 25.43 \\
\hline HT 38 & 0.92 & 23.60 & 2.63 & 25.32 \\
\hline HT 40 & 0.92 & 23.60 & 2.53 & 25.21 \\
\hline HT 28 & 0.92 & 23.60 & 2.44 & 25.13 \\
\hline HT 48 & 0.85 & 23.53 & 2.36 & 25.04 \\
\hline HT 39 & 0.83 & 23.51 & 2.28 & 24.96 \\
\hline
\end{tabular}

$g:$ is the value of the predicted genotypic effect; $u+g$ : is the mean value plus the genotypic effect.

Table 5. Spearman correlation coefficients and Bootstrap confidence intervals $(95 \%$ probability) calculated between the rankings of grain yield and popping expansion traits of popcorn families.

\begin{tabular}{lccc}
\hline Item & Site 1 & Site 2 & Site 3 \\
\hline Spearman correlation & -0.278 & -0.362 & -0.278 \\
Standard error & 0.147 & 0.129 & 0.135 \\
Bootstrap lower limit & -0.566 & -0.614 & -0.542 \\
Bootstrap upper limit & 0.009 & -0.110 & -0.015 \\
\hline
\end{tabular}

grain production and forage depending on variables such as earliness, sowing season, climatic and soil conditions, sowing density, fertilization, crop management, that is, environmental conditions that determine their productive behavior, in this case, qualitative behavior.

The classification (order) of genotypes in this study was not dependent on environmental conditions in which they were established (interaction genotype $\mathrm{x}$ environment not significant, $\mathrm{p}>0.05$ ). In the breeding programs, interaction between genotype and environment entails the selection of genotypes that show greater stability in a range of environments where they are to be introduced, as well as evaluating the productive potentials and their possible limitations in each environment (Contreras and Krarup, 2000). Knowledge of the magnitude of genotype interaction with environmental factors (whether these are due to site, sowing year, soil type, or technology level used among others) is of great importance for farmers and plant improvement programs which aim to minimize the differences in productivity between the genotypes that are dependent on the environment in which they are being cultivated (Yue et al., 1997; Scapim et al., 2000; Contreras and Krarup, 2000). 


\section{CONCLUSIONS}

The top-cross hybrids showed an adequate grain yield, but the quality of the popcorn (measured through popping expansion of the grains) was still below the standards of popcorn imported in Brazil.

Grain production was a moderate heritability trait, meanwhile popping expansion showed greater additive genetic control. These results are promising for the advancement of the breeding program conducted in Brazil.

The heterogeneousness variance model used in the REML-BLUP mixed linear models allowed adequate adjustment of the genetic values considering a joint analysis of the three environments. For this reason, it was possible to identify popcorn genotypes with better yield and popping expansion. In general, the hybrids with greater grain yield were not those with the highest popping expansion, thus confirming previous studies of this crop. Genotypic selection must be conducted considering those genotypes that show both a greater popping expansion and a high grain yield.

\section{RESUMEN}

Evaluación de híbridos top-cross de maíz-roseta usando modelos lineales mixtos. El mercado del maízroseta (Zea mays L.) está en continuo crecimiento en Brasil, lo cual ha demandado el desarrollo de cultivares adaptados a las condiciones locales. Por ello, los objetivos del presente trabajo fueron evaluar híbridos top-cross de maíz-roseta en función de la capacidad de expansión y el rendimiento de los granos, en diferentes regiones ecogeográficas de Brasil; estimar componentes de varianza usando Máxima Verosimilitud Restringida (REML) y predecir los valores genotípicos a través de la Mejor Predicción Linear Insesgada (BLUP). La evaluación genética consideró un modelo lineal con una estructura de varianza residual (ambiental) heterogénea. La prueba de la razón de verosimilitud (restringida) evidenció diferencias significativas $(p<0,01)$ para el efecto genotípico. La producción de granos mostró ser una característica de heredabilidad media $\left(h^{2}=0,26-0,39\right)$. En la capacidad de expansión se evidenció un mayor control genético aditivo $\left(\mathrm{h}^{2}=0,58-0,85\right)$. Las correlaciones genéticas y de Spearman entre las características fueron negativas, indicando que la selección basada en el rendimiento de granos tendría un efecto negativo sobre la capacidad de expansión. Los híbridos top-cross presentaron un rendimiento de grano adecuado, sin embargo, la calidad de la roseta estuvo por debajo de los estándares comerciales.

Palabras clave: capacidad de expansión, REML, BLUP, mejoramiento, Zea mays.

\section{LITERATURE CITED}

Akaike, H. 1974. A new look at the statistical model identification. Trans. Autom. Control 19:716-723.

Arnhold, E., F. Mora, y A. Deitos. 2006. Correlaciones genéticas en familias $\mathrm{S}_{4}$ de maíz (Zea mays). Cien. Inv. Agr. 33(2):25-131.

Campbell, B.T., and M.A. Jones. 2005. Assessment of genotype $\mathrm{x}$ environment interactions for yield and fiber quality in cotton performance trials. Euphytica 144:69-78.

Carpentieri-Pípolo, V., H.W. Takahashi, R.M. Endo, M.R. Petek, e A.L. Seifert. 2002. Correlações entre caracteres quantitativos em milho pipoca. Hortic. Brás. 20:551-554.

Coimbra, R.R., G.V. Miranda, J.M.S. Viana, e C.D. Cruz. 2001. Correlações entre caracteres na população de milho-pipoca DFT-1 Ribeirão. Revista CERES 48:427-435.

Contreras, S., y C. Krarup. 2000. Interacción genotipo por ambiente en cinco cultivares de espárrago (Asparragus officinalis L.). Cien. Inv. Agr. 27:133-139.

Cruz, C.D., A.D. Regazzi, e P.C.S. Carneiro. 2004. Modelos biométricos aplicados ao melhoramento genético. 480 p. Universidade Federal de Viçosa, Viçosa, Brasil.

Gonçalves-Vidigal, M.C., F. Mora, T.S. Bignotto, R.E.F. Munhoz, and L.D. Souza. 2008. Heritability of quantitative traits in segregating common bean families using a Bayesian approach. Euphytica 164:551-560.

Gauch, H.G., and R.W. Zobel. 1988. Predictive and postdictive success of statistical analysis of yield trials. Theor. Appl. Genet. 76:1-10.

Lee, E.A., T.K. Doerksen, and L.W. Kannenberg. 2003. Genetic components of yield stability in maize breeding populations. Crop Sci. 43:2018-2027.

Marcelino, S.D.R., e A.F. Iemma. 2000. Métodos de estimação de componentes de variância em modelos mistos desbalanceados. Sci. Agric. 57:643-652.

Matta, F.P., e J.M.S. Viana. 2001. Testes de capacidade de expansão em programas de melhoramento de milho pipoca. Scientia Agrícola 58:845-851.

Mora, F., y E. Arnhold. 2006. Inferencia Bayesiana y metodología de modelos lineales mixtos aplicados al mejoramiento del maíz. Cien. Inv. Agr. 33:217-223.

Mora, F., y S. Perret. 2007. Aplicación de técnicas bayesianas en el análisis genético de árboles forestales. Bosque 28:198-206.

Mora, F., y C.A. Scapim. 2007. Predicción de valores genéticos del efecto de poblaciones de maíz evaluadas en Brasil y Paraguay. Agric. Téc. (Chile) 67:139-146. 
Newcom, D.W., T.J. Baas, K.J. Stalder, and C.R. Schwab. 2005. Comparison of three models to estimate breeding values for percentage of loin intramuscular fat in Duroc swine. J. Anim. Sci. 83:750-756.

Nunes, H.V., G.V. Miranda, J.C.C. Galvão, L.V. Souza, e L.J.M. Guimarães. 2002. Adaptabilidade e estabilidade de cultivares de milho-pipoca por meio de dois métodos de classificação. Revista Brasileira de Milho e Sorgo 1:78-88.

Pacheco, C.P., E.E.G. Gama, P.E. Guimarães, M.X. Santos, e A.S. Ferreira. 1998. Estimativas de parâmetros genéticos nas populações CMS-42 e CMS-43 de milho-pipoca. Pesq. Agropec. Bras. 33:1995-2001.

Patterson, H.D., and R. Thompson. 1971. Recovery of inter-block information when blocks sizes are unequal. Biometrika 58:545-554.

Piepho, H.P., and J. Möhring. 2006. Selection in cultivar trials - Is It Ignorable? Crop Sci. 46:192-201.

Resende, M.D.V. 2002. Genética biométrica e estatística no melhoramento de plantas perenes. 975 p. Embrapa Informação Tecnológica, Brasilia, Brasil.

Rivas, R.P., y P.B. Barriga. 2002. Capacidad combinatoria para rendimiento de grano y caracteres de calidad maltera en cebada (Hordeum vulgare L.). Agric. Téc. (Chile) 62:347-356.

Santos, J.F., J.M.S. Viana, A.A. Vilarinho, and T.M.M. Câmara. 2004. Efficiency of $\mathrm{S}_{2}$ progeny selection strategies in popcorn. Crop Breed. Appl. Biotechnol. 4:183-191.

SAS Institute. 1996. Statistical analysis system user's guide. 956 p. SAS Institute, Cary, North Carolina, USA.

Sawazaki, E. 1995. Melhoramento do milho-pipoca. 21 p. Instituto Agronômico de Campinas, Campinas, São Paulo, Brasil.
Scapim, C.A., V.R. Oliveira, A.L. Braccini, C.D. Cruz, C.A.B. Andrade, and M.C.G. Vidigal. 2000. Yield stability in maize (Zea mays L.) and correlations among the parameters of the Eberhart and Russell, Lin and Binns and Huehn models. Genet. Mol. Biol. 23:387-393.

Scapim, C.A., R.J.B. Pinto, A.T. Amaral-Júnior, F. Mora, and T.S. Dandolini. 2006. Combining ability of white grain popcorn populations. Crop Breed. Appl. Biotechnol. 6:136-143.

Silva, J.C., G.W. Dutkowski, and N.M.G. Borralho. 2005. Across-site heterogeneity of genetic and environmental variances in the genetic evaluation of Eucalyptus globulus trials for height growth. Ann. For. Sci. 62:183-191.

Soto, P.O., E.B. Jahn, y S.S. Arredondo. 2004. Mejoramiento del porcentaje de proteína en maíz para ensilaje con el aumento y parcialización de la fertilización nitrogenada. Agric. Téc. (Chile) 64:156162.

Schwarz, G. 1978. Estimating the dimension of a model. Ann. Stat. 6:461-464.

Thompson, W.A. 1962. The problem of negative estimates of variance components. Ann. Math. Stat. 33:273289.

Vilarinho, A.A., J.M.S. Viana, J.F. Santos, e T.M.M. Câmara. 2003. Eficiência da seleção de progênies $S_{1} e$ $\mathrm{S}_{2}$ de milho-pipoca, visando à produção de linhagens. Bragantia 62:9-17.

Von Pinho, R.G., A. Brugnera, C.A.P. Pacheco, e M.S. Gomes. 2003. Estabilidade de cultivares de milhopipoca em diferentes ambientes, no Estado de Minas Gerais. Revista Brasileira de Milho e Sorgo 2:53-61.

Yue, G.L., K.L. Roozeboom, W.T. Schapaugh, and G.H. Liang. 1997. Evaluation of soybean cultivars using parametric and nonparametric stability estimates. Plant Breed. 116:271-275. 